\title{
Assessment of possible damaged areas due to landslide-induced waves at a constructed reservoir using empirical approaches: Kurtun (North Turkey) Dam reservoir area
}

\author{
A. Akgün \\ Karadeniz Technical University, Geological Engineering Department, Trabzon, Turkey \\ Received: 6 February 2011 - Revised: 16 April 2011 - Accepted: 18 April 2011 - Published: 12 May 2011
}

\begin{abstract}
Landslide-induced wave in lakes or offshore is a natural hazard of significant concern throughout the world. In Turkey, several dam reservoir areas suffer from this problem, motivating for the exploration of this phenomenon. In this study, the potential for landslide-induced wave generation and the possible adverse effects of such an event were investigated for the Kurtun Dam reservoir area. This area is prone to translational debris-type landslides, and such slides represent a threat with respect to wave generation. To investigate this problem, a potential landslide was initially inspected with respect to key geometrical and index parameters, such as the internal friction angle and unit weight of the landslide material. After obtaining these data, the potential of sub-aerial landslide-induced wave characteristics such as wave height, wave run-up on the opposite slope and wave velocity were calculated using existing empirical relationships. Based on the obtained wave properties, a potential damage assessment was performed for vulnerable areas in recognition of the fact that the Kurtun Dam and Kurtun district are threatened by potential wave occurrence. According to the findings obtained from the potential damage assessment, it was determined that the Kurtun district and the Kurtun portion of the Kurtun-Gumushane highway are located within the run-up impact area. However, the Kurtun Dam was determined to be relatively safe due to the distance between the landslide area and the dam.
\end{abstract}

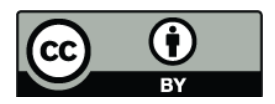

Correspondence to: A. Akgün (aykutakgun@gmail.com)

\section{Introduction}

Rapid landslides can entre reservoirs and, depending on their velocity, generate impulsive waves, which propagate, reaching sillages and causing considerable destruction, as has occurred previously (Pastor et al., 2009). Two dramatic examples of such events are the Vajont Dam disaster and the Lituya Bay megatsunami event. In both examples, extremely large rock masses slid into reservoirs, and these slides produced waves hundreds of metres in height. The Vajont Dam disaster was particularly serious, as it caused the deaths of 2000 people, and this case has become an important example of such problems, prompting other communities to take remedial measures (Genevois and Ghirotti, 2005; Bosa and Petti, 2011). To evaluate the risks posed by these waves, it is necessary to use models that can accurately provide information on all slide phenomena such as triggering, propagation, entering the reservoir and the propagation of the resulting impulsive wave. To model all these aspects, engineers and geologists must use several empirical relationships and a series of models. The assessment of impulsive waves triggered by landslides in artificial reservoirs plays an important role in the planning and management of dams and reservoirs. In artificial basins where significant landslide risk exists, water is kept well below the maximum level, thereby preventing the potential impulse wave from overtopping the dam and reducing the wave run-up on the opposite shorelines (Panizzo et al., 2005). In the literature, there are several studies on the modelling of landslide-generated waves and the adverse impacts of such waves. These studies have been grouped into three categories, including mathematical theory (Stoker, 1957; Prins, 1958; Kranzer and Keller, 1960; Le Mehaute and Wang, 1996), physical modelling experiments

Published by Copernicus Publications on behalf of the European Geosciences Union. 
(Wiegel, 1955; Wiegel et al., 1970; Kamphuis and Bowering, 1970; Slingerland and Voight, 1979, 1982; Huber and Hager, 1997; Watts, 1997; Walder et al., 2003; Fritz et al., 2001, 2004; Panizzo et al., 2005; Pastor et al., 2009; Basu et al., 2010), and numerical simulations (Heinrich, 1992; Watts, 1997; Monaghan and Kos, 2000; Watts et al., 2005; Wieczorek et al., 2007; Romstad et al., 2009; Biscarini, 2010). In this study, empirical relationships based on experimental models proposed by Hall and Watts (1953), Chow (1960), Weigel (1964), Noda (1970), Synolakis (1987) and Huber and Hager (1997) were applied to a landslide developing at the Kurtun Dam reservoir area (Gumushane, Northeastern Turkey). The potential landslide was first recognized in 2002 by the State Hydraulic Works (DSI) during surveys of the reservoir area. The developing landslide could potentially generate a wave extending across the reservoir area. This paper aims to describe the potential landslide mass, to discuss monitoring of the landslide movement using geodetic deformation measurements, and to investigate empirical models for determination of the height, speed, run-up and adverse effects of the potential landslide-generated waves. For this purpose, index parameters and some geometric features of the landslide mass were initially determined. Using these features, the results of modelling waves in the reservoir area using previously developed models to derive a range of values for potential wave height, run-up, and speed were examined. Then, based on these findings, the areas potentially at risk were determined in a geographical information system (GIS) environment.

\section{Geographical and geological settings}

The study area is located in the southern part of the Eastern Black Sea region of Turkey (Fig. 1). Due to the climate characteristics of this zone and the hydrodynamic properties of its rivers, the Eastern Black Sea Region has become the site of important hydropower structures, such as dams and hydroelectric power plants. Kurtun dam is located in the Eastern Black Sea Region, $27 \mathrm{~km}$ northwest of the town of Torul on the Harsit River in Gumushane province. The main purpose of this dam is to provide energy and the facility has an annual output of 198 GWh (State Hydraulic Works, 2010). Construction of the dam embankment began in 1997 and finished in 1999. The reservoir impounding process began on 8 February 2002, and the water level reached an elevation of $650 \mathrm{~m}$ on 30 April 2002 (Ozkuzukiran et al., 2006). Kurtun dam is $133 \mathrm{~m}$ high from the riverbed, and the crest extends $300 \mathrm{~m}$. The dam is constructed on a relatively narrow valley with steeply sloping walls approximately $45 \mathrm{~m}$ apart. Abutment slopes average $61^{\circ}$ and $52^{\circ}$ for the left and right abutments, respectively.

The lithological units in the study area consist mainly of thick volcanic, volcano-clastic and intrusive rocks (Fig. 2). According to Guven (1993), the basement unit of the study

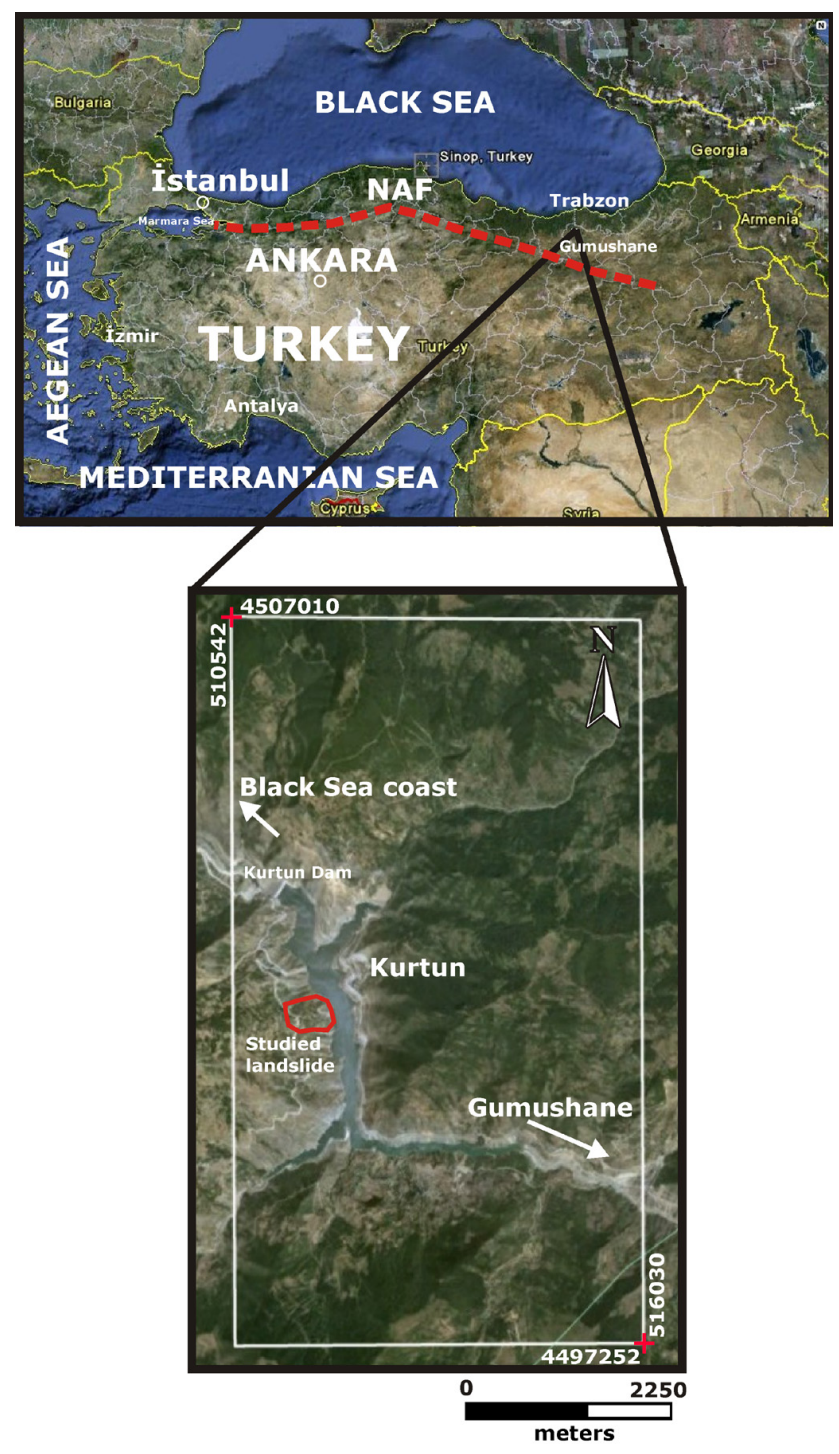

Fig. 1. Location map of the study area and a general view of the Kurtun Dam (NAF: North Anatolian Fault is presented by red dashed line) (Google Earth).

area is the Turonian-Santonian age Catak formation $(\mathrm{Ct})$, which is composed of clay, sandy limestone and andesite interbedded with pyroclastic deposits. The Catak formation is conformably overlain by the Kizilkaya formation $(\mathrm{Kz})$ consisting of biomicritic limestone, dacite with marl and pyroclastics. The Kizilkaya formation is conformably overlain by the Campanian-Maastrichtian age Caglayan formation $(\mathrm{Cg})$ consisting of clayey sandy limestones, basalts interbedded with marls, andesites and pyroclastics. These sequences in the study area were cross-cut by the Kurtun granitoide (Kr) intruded during the Upper Cretaceous. The intrusion consists of hornblende and biotite. This intrusion is in turn cross-cut by dikes of quartz porphyry, dacite and dolerite (Ceryan et al., 2008). Considerable hydrothermal alterations at the outer 


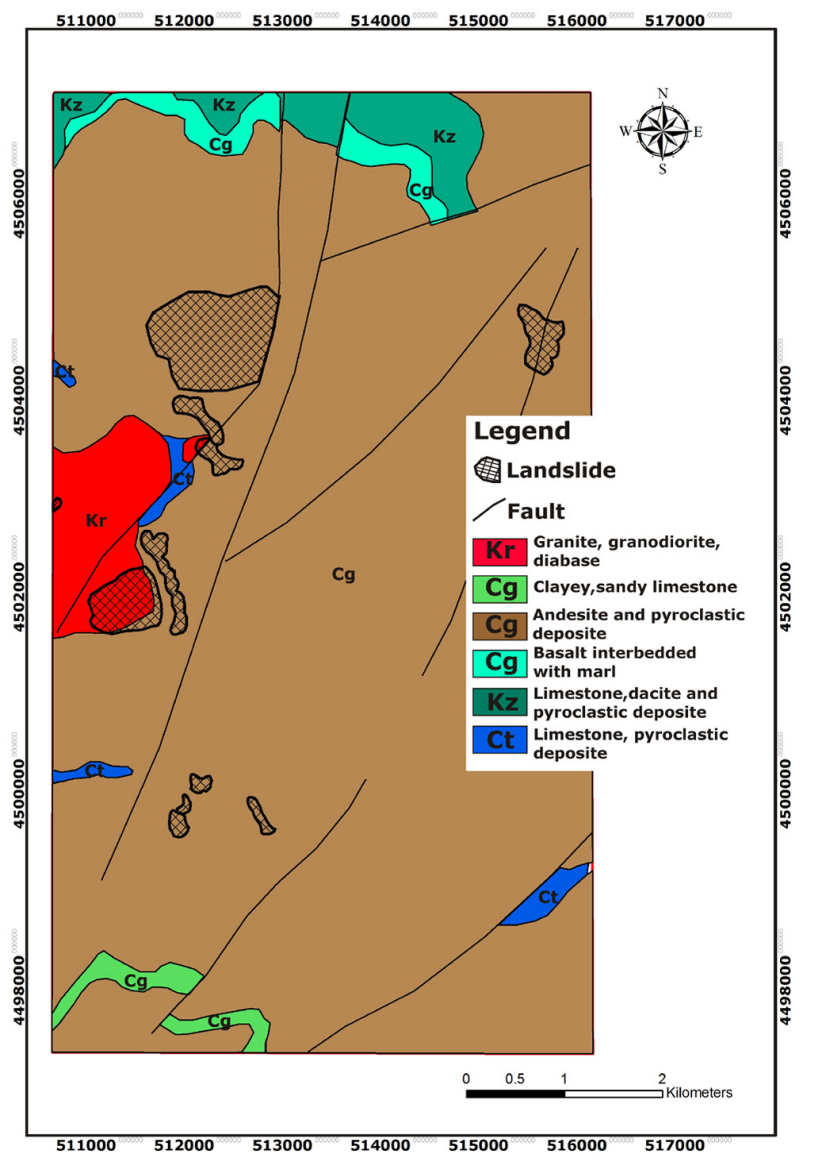

Fig. 2. Generalized geological map of the study area and its vicinity.

zones of the Kurtun granitoid and along the faults can be observed in the area.

\section{Engineering geology of the Hardisagir landslide}

In the Northern part of Turkey, large landslides such as the Catak (Genc, 1993), Dagkoy (Ocakoglu et al., 2002), Kuzulu (Gokceoglu et al., 2005), Tuzla (Gokceoglu et al., 2009) and Tortum (Duman, 2009) are frequent. The Hardisagir landslide, which forms the basis of this study, is a large landslide located on the left abutment of the Kurtun Dam reservoir area. The distance between the dam body and the landslide mass is approximately $1800 \mathrm{~m}$ (Fig. 1). The main triggering for the landslide is considered to be precipitation, due to the fact that major earthquakes have not been recorded at or near the study area in recent times (the North Anatolian Fault located approximately $150 \mathrm{~km}$ south of the study area; Fig. 1). A close inspection of the local geology of the landslide mass revealed three lithological units (Fig. 3). From bottom to top, diabase, granite-granodiorite and slope debris units were determined and mapped (Fig. 3). The landslide occurred mainly on the slope debris material, which
Table 1. The landslide characteristics and the other values used in calculations

\begin{tabular}{ll}
\hline Characteristic & Value \\
\hline Elevation of top of scarp & $1035 \mathrm{~m}$ \\
Elevation of base of scarp & $850 \mathrm{~m}$ \\
Slide length (base of scarp to toe) & $645 \mathrm{~m}$ \\
Average slide width & $330 \mathrm{~m}$ \\
Maximum slide width & $340 \mathrm{~m}$ \\
Average slided mass thickness & $26 \mathrm{~m}$ \\
Landslide travel distance to shore of reservoir & $645 \mathrm{~m}$ \\
Density of slided mass & $2.5 \mathrm{t} \mathrm{m}^{-3}$ \\
Maximum slope gradient of landslide to reservoir & $35^{\circ}$ \\
Average slope gradient of opposite shore & $45^{\circ}$ \\
Internal friction angle & $35^{\circ}$ \\
Landslide area & $88000 \mathrm{~m}^{2}$ \\
Maximum volume of landslide mass & $1320000 \mathrm{~m}^{3}$ \\
Maximum water depth of reservoir & $150 \mathrm{~m}$ \\
\hline
\end{tabular}

was composed of granite, granodiorite and diabase blocks (Fig. 4). During field studies, it was observed that the landslide material belonged to an old landslide mass and that heavy precipitation caused this material, which was critically balanced, to be triggered again. At the top of the landslide topography, tension cracks 40 and $50 \mathrm{~cm}$ in length were observed. The triggering point of the landslide, namely the top of scarp, was recorded at an altitude of $1.035 \mathrm{~m}$ (Fig. 3; Table 1). The elevation of the base of scarp was determined to be $850 \mathrm{~m}$. The distance from the base of scarp to the toe of the mass was $645 \mathrm{~m}$. The geometrical shape of mass was an ellipsoid (Fig. 3). To facilitate the calculation of potential wave properties, average and maximum slide widths were measured and determined to be 330 and $340 \mathrm{~m}$, respectively (Table 1). From the drilling data collected in the area, the average thickness of the landslide mass was determined to be $26 \mathrm{~m}$. The density of the material is one of the basic inputs for calculating wave properties. In this context, the density of the slide material was found to be $2.5 \mathrm{t} \mathrm{m}^{-3}$. The surface area of the landslide mass was calculated to be $88000 \mathrm{~m}^{2}$, and using both this surface area and average thickness values, the maximum volume of the landslide mass was obtained as $1320000 \mathrm{~m}^{3}$ (Table 1). In addition to the aforementioned landslide mass, small-scale debris flows and debris slides also occurred, both on the slide mass and in its very close vicinity (Fig. 3). Some of these movements were located near the maximum water level of the reservoir. As a result, the lower part of these mass movements remained at or below the water level. Therefore, there is also the potential for underwater landslide-induced waves to occur.

The first engineering geology studies in the area were performed in 1990 by DSI. However, after the aforementioned landsliding began in 2002, a monitoring programme was started in the area. For this purpose, geodetic measurements 


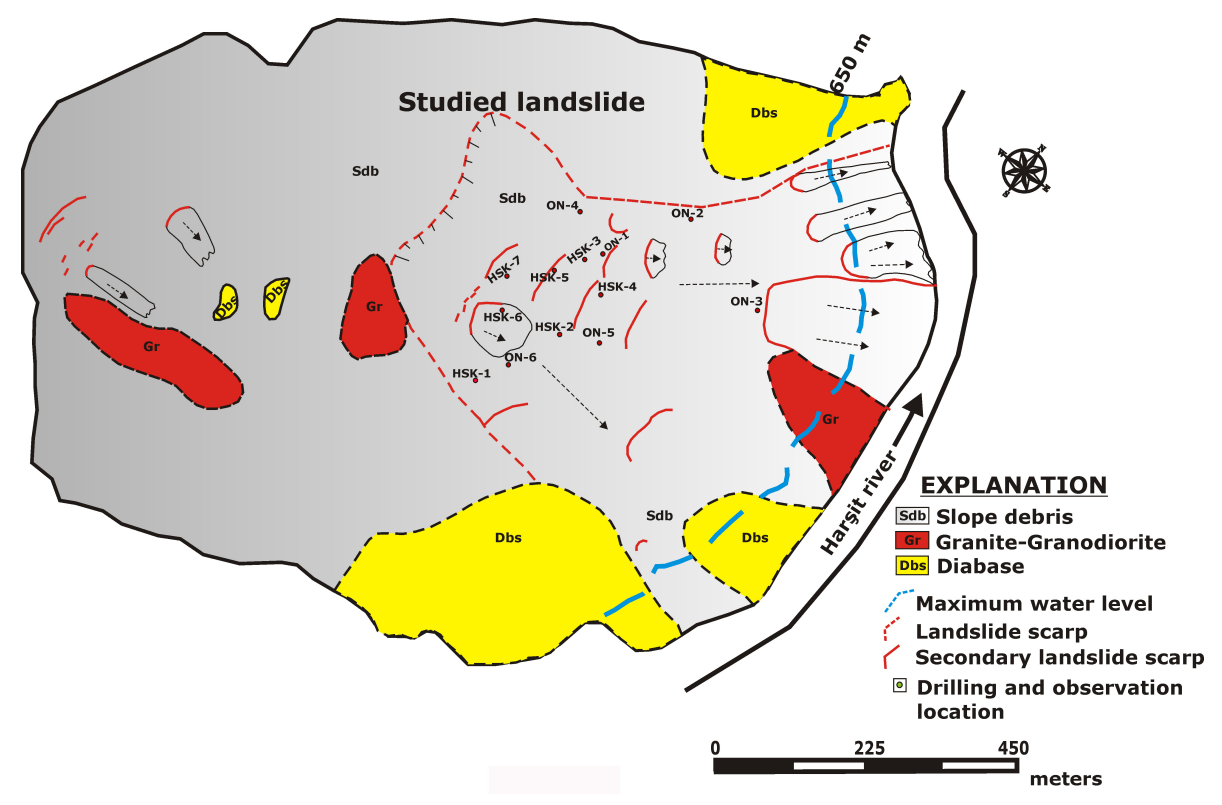

Fig. 3. Detailed lithology map of the Hardisagir landslide and its vicinity (Modified from Kutlu, 2009).
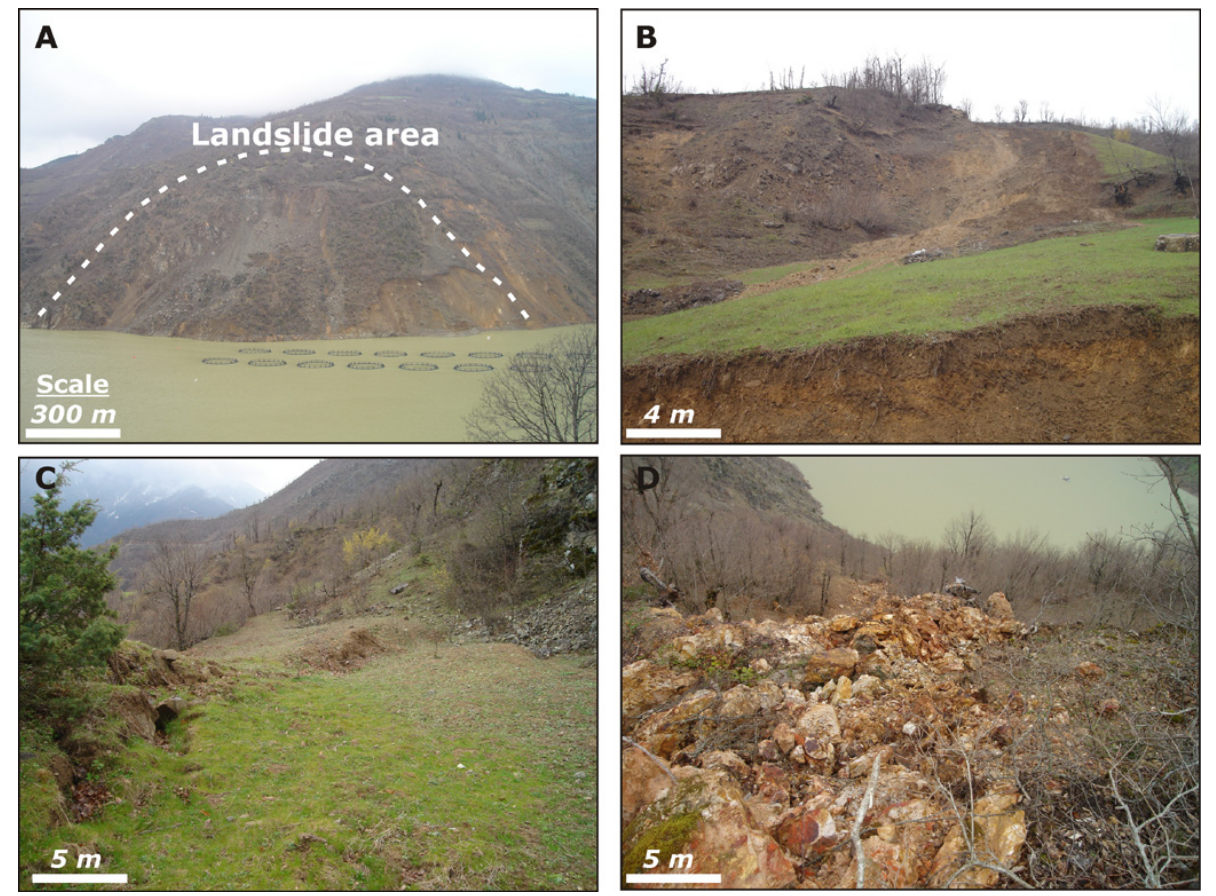

Fig. 4. Views of the landslide area and the slope debris material: (A) A close view of the landslide from the opposite slope, (B) A part of the main scarp of the landslide, (C) A deformation example on the landslide mass and (D) A view of the slope debris material of the landslide.

were performed at six observation locations (Fig. 3) during the period from 2002 to 2008 . These deformation measurements are presented in Table 2. In Fig. 5, a graphical representation of these deformation measurements is also presented. According to the graphs, the most considerable deformations could be observed at observation location 1, 2, 3 and 4. At these locations, a vertical deformation changing from $1 \mathrm{~m}$ to $3 \mathrm{~m}$ was observed. In addition to this observation, a horizontal deformation could also be determined at the same observation locations. All these deformation measurements revealed that the inspected landslide shows an important vertical movement in the area. In addition to 
Table 2. Deformation measurements obtained by geodetic records and by observation pipes in the bore holes.

\begin{tabular}{|c|c|c|c|c|c|c|c|c|c|c|c|c|c|c|c|}
\hline \multicolumn{4}{|c|}{ Measurements in 24.05.2002 (A) } & \multicolumn{4}{|c|}{ Measurements in 20.06.2002 (B) } & \multicolumn{4}{|c|}{ Measurements in 04.04.2003 (C) } & \multicolumn{4}{|c|}{ Measurements in 02.06 .2005 (D) } \\
\hline Obs. No & $\mathrm{X}$ & Y & $\mathrm{Z}(\mathrm{m})$ & Obs.No & $\mathrm{X}$ & $\mathrm{Y}$ & $\mathrm{Z}(\mathrm{m})$ & Obs. No & $\mathrm{X}$ & Y & $\mathrm{Z}(\mathrm{m})$ & Obs.No & $\mathrm{X}$ & Y & $\mathrm{Z}(\mathrm{m})$ \\
\hline ON1 & 511159 & 4503649 & 924 & ON1 & 511159 & 4503649 & 924 & ON1 & 511160 & 4503649 & 924 & ON1 & 511161. & 4503651 & 922 \\
\hline $\mathrm{ON} 2$ & 511213 & 4503776 & 820 & $\mathrm{ON} 2$ & 511213 & 4503776 & 820 & ON2 & 511213 & 4503776 & 820 & ON2 & 511214. & 4503651 & 819 \\
\hline ON3 & 511016 & 4503804 & 884 & ON3 & 511016 & 4503804 & 884 & ON3 & 511016 & 4503804 & 884 & ON3 & 511016. & 4503804 & 884 \\
\hline ON4 & 510861 & 4504113 & 890 & ON4 & 510861 & 4504113 & 890 & ON4 & 510861 & 4504113 & 889 & ON4 & 510861 & 4504113 & 890 \\
\hline ON5 & 510925 & 4504890 & 673 & ON5 & 510925 & 4504890 & 673 & ON5 & 510925 & 4504890 & 673 & ON5 & 510925 & 4504890 & 673 \\
\hline ON6 & 510773 & 4504905 & 719 & ON6 & 510773 & 4504905 & 719 & ON6 & 510773 & 4504905 & 719 & ON6 & 510773 & 4504905 & 719 \\
\hline
\end{tabular}

\begin{tabular}{|c|c|c|c|c|c|c|c|c|c|c|c|c|c|c|c|}
\hline \multicolumn{4}{|c|}{ Measurements in 21.12.2006 (E) } & \multicolumn{4}{|c|}{ Measurements in 26.04.2007 (F) } & \multicolumn{4}{|c|}{ Measurements in 11.07.2008 (G) } & \multicolumn{4}{|c|}{ Measurements in $25.11 .2008(\mathrm{H})$} \\
\hline Obs. No & $\mathrm{X}$ & $\mathrm{Y}$ & $\mathrm{Z}(\mathrm{m})$ & Obs. No & $\mathrm{X}$ & $\mathrm{Y}$ & $\mathrm{Z}(\mathrm{m})$ & Obs. No & $\mathrm{X}$ & $\mathrm{Y}$ & $\mathrm{Z}(\mathrm{m})$ & Obs. No & $\mathrm{X}$ & $\mathrm{Y}$ & $\mathrm{Z}(\mathrm{m})$ \\
\hline ON1 & 511163 & 4503651 & 921 & ON1 & 511164 & 4503652 & 921 & ON1 & 511166 & 4503652 & 920 & ON1 & 511165 & 4503652 & 919 \\
\hline ON2 & 511215 & 4503778 & 819 & ON2 & 511215 & 4503778 & 819 & ON2 & \multicolumn{3}{|c|}{ No measurement } & ON2 & \multicolumn{3}{|c|}{ No measurement } \\
\hline $\mathrm{ON} 3$ & 511016 & 4503804 & 884 & ON3 & 511016 & 4503805 & 884 & ON3 & 511016 & 4503804 & 884 & ON3 & 511015 & & 885 \\
\hline ON4 & 510861 & 4504113 & 889 & ON4 & 510861 & 4504113 & 890 & ON4 & 510861 & 450 & 889 & ON4 & 510860 & 4504113 & 890 \\
\hline ON5 & 510925 & 4504890 & 673 & ON5 & 510925 & 4504890 & 672 & ON5 & 510925 & 4504890 & 673 & ON5 & 510925 & 4504890 & 673 \\
\hline ON6 & 510773 & 4504905 & 719 & ON6 & 510773 & 4504905 & 719 & ON6 & 510773 & 4504905 & 719 & ON6 & 510773 & 4504905 & 719 \\
\hline
\end{tabular}

\begin{tabular}{ll} 
Bore Hole & Deformation Depth $(\mathrm{m})$ \\
\hline HSK1 & 23 \\
HSK2 & 24 \\
HSK3 & 16 \\
HSK4 & - \\
HSK5 & No deformation \\
HSK6 & - \\
HSK7 & 12 \\
\hline
\end{tabular}
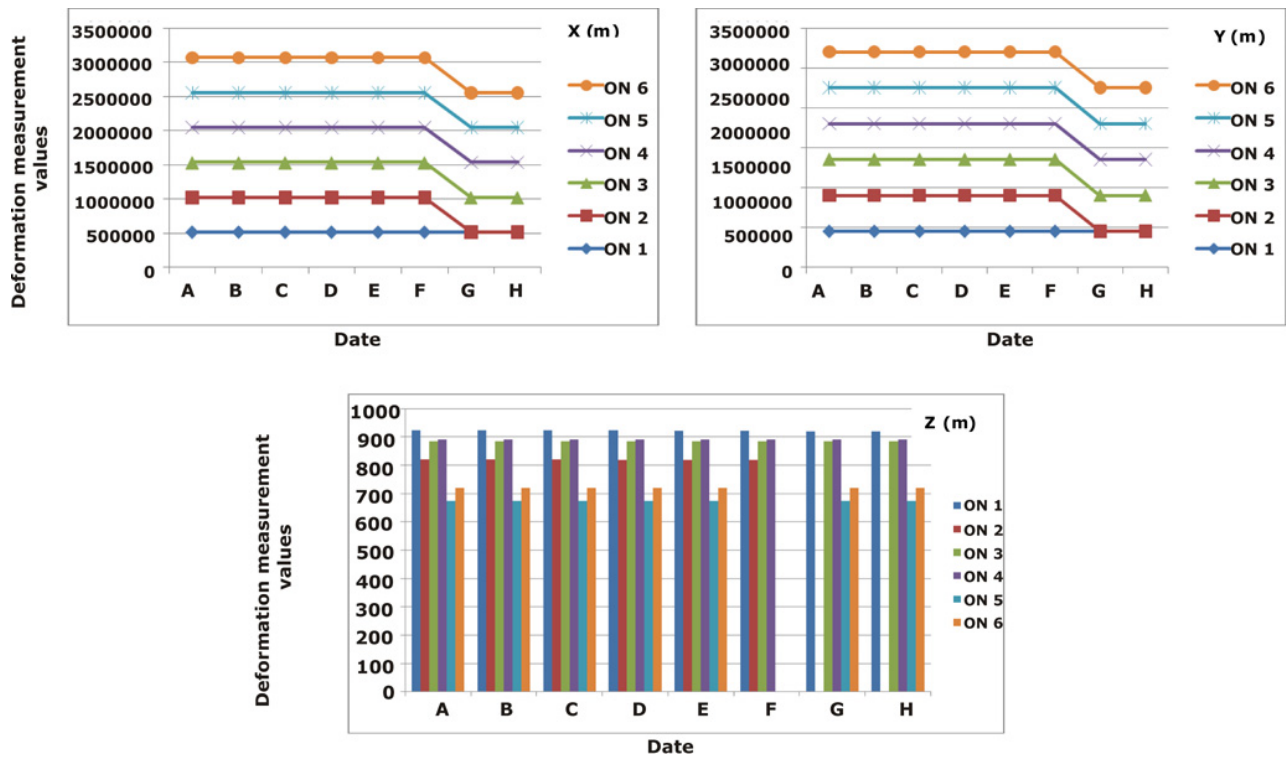

Fig. 5. Graphs showing the measured deformation results. The A, B, C, D, E, F, G and H are the observation date given in Table 2 .

these measurements, seven bore holes were drilled in the area (HSK1 to HSK7), and observation pipes were placed in these bore holes to determine precisely the slip surface. According to these measurements, the sliding depths were determined to be $23 \mathrm{~m}$ at the HSK-1 bore hole and $12 \mathrm{~m}$ at the HSK-7 bore hole, respectively (Fig. 3). According to the landslide classification system proposed by Varnes (1978), the landslide was determined to be a translational debris slide, and the mass was determined to be active based on the WP/WLI (1993) classification system. 


\section{Potential landslide-induced waves}

To assess the potential for landslide-induced waves to occur in natural and artificial reservoir areas, many methods have been applied. Several empirical and numerical models have been suggested to analyse waves generated by landslides using deductive or inductive approaches (Slingerland and Voight, 1979). More recently, interactions between landslides and water bodies have been incorporated in a hydrodynamic model using force terms (Kofoed-Hansen et al., 2001). To evaluate the potential of landslide-induced waves to cause damage in the Kurtun Dam reservoir area, previously developed models were used to derive a range of potential wave height, run-up and wave speed values. The calculations of these data are based upon the measured parameters for the landslide mass in the study area listed in Table 1.

\subsection{Landslide velocity}

Landslide impact velocity is one of the primary parameters to be used for modelling landslide-induced waves. For this purpose, the velocity relationship proposed by Slingerlands and Vought (1979) was used. According to this relationship, landslide velocity can be modelled as:

$v_{s}=v_{0}+\left[2 g s\left(\sin \beta-\tan \phi_{\mathrm{S}} \cos \beta\right)\right]^{1 / 2}$

where $v_{\mathrm{s}}$ is the slide velocity, computed as a mass sliding on a plane, $v_{0}$ is the initial slide velocity, which is assumed to be $0 \mathrm{~ms}^{-1}, g$ is the gravitational constant $\left(9.81 \mathrm{~ms}^{-2}\right), s$ is the landslide travel distance from the toe of the landslide mass to the water's edge, $\beta$ is slope angle in degrees and $\phi_{\mathrm{s}}$ is the angle of internal friction. The angle of internal friction $\left(\phi_{S}\right)$ for a given soil can be determined by plotting the shear stress and the normal effective stress at which shear failure occurs on a Mohr's Diagram. To accomplish this, direct shear tests with consolidated-drained (CD) condition were performed on the landslide material. $\phi_{\mathrm{s}}$ was found to be $35^{\circ}$ (Table 1). According to the relationship given in Eq. (1) and the measured landslide characteristics given in Table 1, the impact velocity was calculated to be $72.40 \mathrm{~m} \mathrm{~s}^{-1}$.

\subsection{Wave height}

In the case of a rapid movement of the landslide mass into the reservoir water body, the resulting waves will have a certain height, and this height will adversely affect both the Kurtun Dam and the Ozkurtun settlement area. To estimate the adverse effects of landslide-generated waves, the height of these possible waves must be determined. To estimate this height, three different empirical relationships proposed by Noda (1970), Slingerland and Voight (1979) and Huber and Hager (1997) were applied. According to Noda (1970), the wave height can be modelled as:

$\eta=\mathrm{F} \lambda$ where $\eta$ is wave height in metres, $\mathrm{F}$ is the Froude number, which is expressed as $\mathrm{v} /(\mathrm{gd})^{0.5}$ ( $v$ : landslide velocity calculated by Eq. (1), $g$ : acceleration of gravity $\left(9.81 \mathrm{~m} \mathrm{~s}^{-2}\right)$ and $d$ : water depth of the reservoir), and $\lambda$ is the maximum thickness of the landslide mass. Using the velocity of $72.40 \mathrm{~m} \mathrm{~s}^{-1}$ and the Froude number of 1.88, Eq. (2) yields a potential wave height in the reservoir area of $49.07 \mathrm{~m}$.

Slingerland and Voight (1979) used data from a study on Mica Reservoir in British Columbia to refine a previously developed model and developed the following regression equation for first wave height:

$\log \left(\eta_{\max } / d\right)=a+b \log (\mathrm{KE})$

where $a$ and $b$ are constant values, which are -1.25 and 0.71 , respectively, and are neither dependent on the site nor on the reservoir geometry, and $\mathrm{KE}$ is the dimensionless kinetic energy. KE has a value ranging from 1 to 100 and is expressed by Eq. (4).

$\mathrm{KE}=0.5\left(l h w / d^{3}\right)\left(\gamma_{s} / \gamma\right)\left(v_{s} / g d\right)$

where $l$ is the length of the landslide mass, $h$ is the thickness of the landslide body, $w$ is the average landslide width, $d$ is the water depth, $\gamma_{s}$ is the density of the landslide material, $\gamma$ is the density of water $\left(1.0 \mathrm{~g} \mathrm{~cm}^{-3}\right)$ and $v_{\mathrm{s}}$ is the slide velocity. Substituting the above values into Eq. (4) yields a KE value of 7.22, which in turn is substituted into Eq. (3) to yield a wave height of $34.36 \mathrm{~m}$. Huber and Hager (1997) proposed a forecasting model for impulse waves into reservoirs. The input parameters for their model were the slope angle at the impact site, the plunging slide volume $\left(V_{\mathrm{s}}\right)$ over a finite shore distance $(b)$, equal to the width of the slide at impact with the water, the slide velocity and direction at the impact site, the water depth $(d)$ near the impact site, water body bathymetry and the distance (x) from the impact site to the location under consideration (Wieczorek et al., 2003). According to Huber and Hager (1997), wave height $(H)$ can be calculated as:

$H=0.88 \sin \alpha\left(\gamma_{\mathrm{s}} / \gamma\right)^{0.25}\left(V_{\mathrm{s}} / b\right)^{0.5}(d / x)^{0.25}$.

Using the values previously cited for $\alpha, \gamma_{s}, \gamma$, and $d$, a landslide volume $\left(V_{\mathrm{s}}\right)$ of $1320000 \mathrm{~m}^{3}$, a distance $(\mathrm{x})$ of $330 \mathrm{~m}$ to the middle of the reservoir area and a finite shore distance (b) equal to the width of the region of impact along the shore, which correspond to the average width of the landslide $(340 \mathrm{~m})$, Eq. (5) yields a wave height of $32.11 \mathrm{~m}$. The wave height $(H)$ is mainly influenced by the impact angle and secondarily by the specific landslide volume $\left(V_{\mathrm{s}} / \mathrm{b}\right)$. The remaining factors in Eq. (5) are of minor importance (Wieczorek et al., 2003). Based on the above findings for wave height, an average value of $38.51 \mathrm{~m}$ can be proposed for the study area.

\subsection{Wave velocity}

Landslide induced waves propagate in semicircles over an open water surface, and the wave height varies with this propagation direction and the travel distance. The largest waves 
travel in the direction of maximum momentum, while lateral waves travelling along the shore are significantly smaller (Wieczorek et al., 2003). To compute the possible wave velocity in the reservoir area, two empirical relationships were applied. The first relationship was applied by Wiegel (1964) to determine wave celerity $(C)$. This relationship, given in Eq. (6), can be written as:

$C=[g(\mathrm{~d}+\mathrm{H})]^{0.5}$

A water depth, $d$, of $150 \mathrm{~m}$ in the reservoir area and an average wave height, $H$, of $38.51 \mathrm{~m}$ results in a wave velocity (C) of $43.00 \mathrm{~m} \mathrm{~s}^{-1}$. The second relationship used to calculate wave velocity was proposed by Huber and Hager (1997). According to this relationship, the $C$ value can be found using Eq. (7):

$C=(g \cdot d)^{0.5}$

Based on this relationship, a water depth, $d$, of $150 \mathrm{~m}$ results in a wave velocity of $38.36 \mathrm{~m} \mathrm{~s}^{-1}$. These two results show similar wave velocity values and the average wave velocity for the reservoir area can be given as $40.68 \mathrm{~m} \mathrm{~s}^{-1}$.

\subsection{Wave run-up}

When a landslide mass suddenly moves into a reservoir, the resulting wave often reaches the opposite slope of the landslide, and this phenomenon is known as wave run-up in the literature (Mueller, 1995; Huber and Hager, 1997; Wieczorek et al., 2007). This phenomenon typically destroys all natural landscapes and anthropogenic structures on the opposite slope. To determine the run-up values of possible waves in the study area, four empirical relationships were used. According to Chow (1960), wave run-up on a slope on the opposite shore of a landslide can be calculated using Eq. (8):

$h=v_{\mathrm{s}}^{2} / 2 g$

where $v_{\mathrm{s}}$ is the landslide velocity, which can be found using Eq. (1), and $g$ is the acceleration of gravity. According to this equation, a landslide velocity of $72.40 \mathrm{~m} \mathrm{~s}^{-1}$ results in a wave run-up of $267.16 \mathrm{~m}$. This means that any structure in the reservoir area, such as fishponds, that is in the impact area of the landslide could be expected to be displaced by as much as $267 \mathrm{~m}$. Huber and Hager (1997) also provided a relationship for wave run-up. This equation is as given below:

$R / d=1.25(\pi / 2 \beta)^{0.2}(H / d)^{1.25}(H / L)^{-0.15}$

where $R$ is the wave run-up height over the level of the water body, $\beta$ is the angle of the opposite slope, $H$ is the approaching wave height found using Eq. (5), $L$ is the wave length, which is typically 5 times greater than the water depth and $d$ is the water depth $(150 \mathrm{~m})$. When calculating wave runup values, the $H$ value obtained from Eq. (5) was used by considering the study of Wieczorek et al. (2003). Wieczorek et al. (2003) suggested that the $H$ value proposed by Huber
Table 3. The values calculated by empirical relationships.

\begin{tabular}{ll}
\hline Calculated property and Calculation Method & Obtained Value \\
\hline Landslide Velocity & \\
Noda (1970) & $72 \mathrm{~m} \mathrm{~s}^{-1}$ \\
Wave Height & \\
Slingerland and Voight (1970) & $34 \mathrm{~m}$ \\
Noda (1970) & $49 \mathrm{~m}$ \\
Huber and Hager (1997) & $32 \mathrm{~m}$ \\
Average Wave Height & $38 \pm 9 \mathrm{~m}$ \\
Wave Runup on Opposite Slope & \\
Chow (1960) & $267 \mathrm{~m}$ \\
Huber and Hager (1997) & $30 \mathrm{~m}$ \\
Synolakis (1987) & $61 \mathrm{~m}$ \\
Hall and Watts (1953) & $78 \mathrm{~m}$ \\
Average Wave Runup & $109 \pm 107 \mathrm{~m}$ \\
Wave Velocity & \\
Weigel (1964) & $43 \mathrm{~m} \mathrm{~s}^{-1}$ \\
Huber and Hager (1997) & $38 \mathrm{~m} \mathrm{~s}^{-1}$ \\
Average Wave Velocity & $40 \pm 3 \mathrm{~m} \mathrm{~s}^{-1}$ \\
\hline
\end{tabular}

and Hager (1997) should be used because this value represent the wave height in the middle of the reservoir, and this wave height is considered to be the main source point of the possible wave run-up. Using these values, Eq. (9) yields a wave run-up of $30 \mathrm{~m}$ on the shore opposite the landslide. Another relationship for wave run-up calculations was proposed by Synolakis (1987). According to this relationship, the wave run-up can be calculated as:

$R / d=2.831(\cot \beta)^{0.5}(H / d)^{1.25}$

Using $45^{\circ}$ for the opposite slope angle, $32.11 \mathrm{~m}$ for $H$ and $150 \mathrm{~m}$ for $d$, a potential run-up of approximately $61.83 \mathrm{~m}$ is calculated for the slope opposite the studied landslide. The last relationship used for calculating wave run-up was provided by Hall and Watts (1953). This relationship is given below:

$R / d=3.1(H / d)^{1.15}$

Based on this relationship, the wave run-up was calculated as approximately $79 \mathrm{~m}$. All the calculated wave properties are given in Table 3.

\subsection{Assessment of possible damage to the reservoir area}

To assess the potential adverse effects of landslide-induced waves on the reservoir area, a geographical information system (GIS)-based assessment was carried out using the wave characteristics calculated from the above empirical relationships. In this assessment, two wave properties in particular, run-up and wave velocity, were taken into consideration because these two parameters are especially likely to affect man-made structures such as settlement areas and the dam 


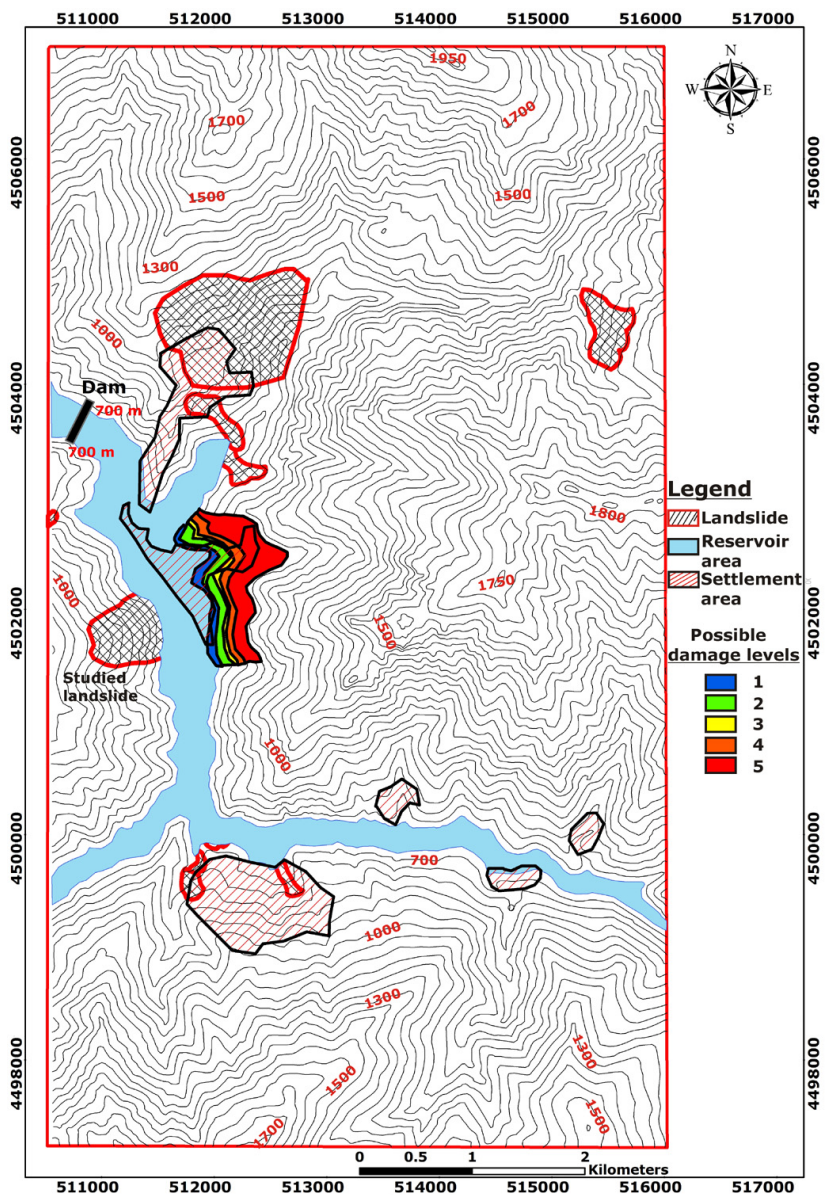

Fig. 6. Potential damage assessment for vulnerable areas using GIS media and visualization of the possible damaged areas.

body located near the site of the potential landslide. As given in Table 3, all the considered wave properties were calculated using more than one empirical relationship, and average values of these properties were also given. When conducting the potential damage assessment for vulnerable areas, all the wave run-up values calculated were taken into consideration. For this purpose, five possible damage levels from 1 to 5 were differentiated (Fig. 6). In this differentiation, level 1 shows the areas that would probably be affected by wave run-up with a $30 \mathrm{~m}$ run-up range. Levels $2,3,4$ and 5 show the possible damaged areas of waves with $61.38 \mathrm{~m}, 78.99 \mathrm{~m}$, $109.38 \mathrm{~m}$ and $267.16 \mathrm{~m}$ run-up ranges, respectively. These results suggest that when the landslide mass enters the reservoir water, the resulting wave will run-up some significant amount on the opposite side of the slope. On the opposite slope of the current site, a new settlement area, Kurtun district, has been established (Fig. 7). After the construction of the Kurtun dam, some parts of the Kurtun district stayed below the reservoir water level. Currently, a new settlement site in the Kurtun district, the DSI camp that was constructed during the Kurtun Dam construction, and the highway connect-

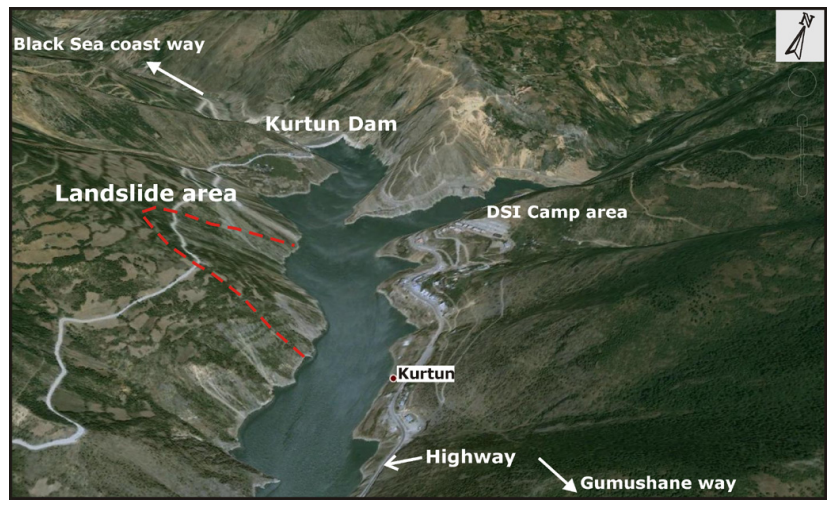

Fig. 7. A close view of the settlement-dam reservoir area relationship (View obtained from Google Earth).

ing Gumushane city to the Black Sea coast are located in the wave run-up impact area (Fig. 6). The settlement areas, Kurtun district and Kurtun Dam, were also digitized. Due to the fact that the crest altitude of the Kurtun dam is approximately $700 \mathrm{~m}$, the dam body was shown at this altitude. The distance between the landslide site and the dam body is approximately $1800 \mathrm{~m}$. As the average wave velocity was calculated to be $40.68 \mathrm{~m} \mathrm{~s}^{-1}$ after entry of the landslide mass into the reservoir, the lateral travel time of the wave created by the landslide was estimated to be $44 \mathrm{~s}$. When considering an average wave height of $38.51 \mathrm{~m}$, it seems unlikely that such a wave will overtop the dam. This prediction remains valid even for the maximum wave height suggested by the above models, $49.07 \mathrm{~m}$, because the highest wave amplitude will be somewhat diminished by the time the wave reaches the dam body. However, the impact of such a wave on the dam body will naturally produce a dramatic effect, and this effect must be taken into account. Because wave impact analysis is beyond the scope of this study, the problem was not handled in detail here. However, a close inspection of Fig. 6 also reveals other settlement areas close to the landslide site. These areas should also be evaluated as areas that could potentially be threatened by a landslide-induced wave. One of these areas is located on the north side of the landslide area, and the distance between the landslide and the settlement area is approximately $1400 \mathrm{~m}$. When considering this distance and comparing it with the distance between the landslide site and the opposite side of the reservoir, it is clear that it is unlikely to be a large potential for run-up in this area. However, minor effects of a potential wave could be expected in this area. For this reason, the possible adverse effects in this area should not be neglected. 


\section{Discussions and conclusions}

In the present study, the potential properties of landslideinduced waves in the Kurtun Dam reservoir area were calculated using several empirical relationships. Specifically, wave height, wave run-up and wave velocity were determined using three, four and two empirical equations, respectively. The purpose of using more than one relationship was to strengthen and to compare the results obtained. When calculating the wave height, the use of three empirical relationships yielded extremely similar results. The same situation was encountered when calculating the wave velocity. However, the relationships used for calculating wave run-up values showed a considerable inconsistency among the results obtained. For example, while the relationship proposed by Chow (1960) gave a very high run-up value, the other relationships used gave plausible values. When examining the wave run-up calculation equations, it will be seen that the equation proposed by Chow (1960) uses only two input parameters to calculate the wave run-up value. In this equation, there is no input parameter with respect to the water body. However, it is very clear that the handling problem is somewhat complicated, and to overcome this complexity, more parameters, including characteristics of the water body and the opposite slope, should be evaluated. For this reason, other scientists, such as Huber and Hager (1997), Synolakis (1987) and Hall and Watts (1953) proposed the use of the other equations, which were employed in this study. These factors illustrate why the wide range of calculated wave run-up values was obtained in this study due to variations in the input parameters considered by different researchers. As a result of this situation and to avoid errors in the potential damage assessment, all the calculated wave run-up values were taken into account. In this context, the areas of significant wave threat were determined and their possible damage levels were assessed. According to the results of the potential damage assessment for vulnerable areas, Kurtun district and the DSI camp area are located in the 2nd and 3rd damage level zones of the potential landslide-induced wave impact area. In addition, the highway that connects Gumushane with the Black Sea coast is also within the same potential damage zone. Although the population of Kurtun district is not very high, at 3000 people, the vehicle traffic on the aforementioned highway is relatively dense. For this reason, the occurrence of a landslide-induced wave could result in the injury or death of many people, and the road could be damaged by the wave. Based on the calculated wave height and wave velocity values, the likelihood of damage to the Kurtun Dam itself seems relatively low, consistent with the relatively large distance between the landslide location and dam body location. Future work is proposed to address this problem using two- or three-dimensional numerical modelling and simulation. In this way, the potential damage estimated in this study may be evaluated in greater detail and visual results may be presented. Because this is the first scientific study of possible adverse landslide-induced wave impacts on reservoir areas in Turkey, this study may be used as an example for solving similar problems in other locations.

Acknowledgements. This project is supported by the Karadeniz Technical University Scientific Research Fund. The author is grateful to the State Hydraulics Works 22nd District Management for providing data. The author also thanks Oguzhan Erkan for his assistance during the field studies and laboratory experiments. Thanks also to the two anonymous reviewers and the journal editor for their constructive suggestions for improving the scientific quality of this paper.

Edited by: O. Katz

Reviewed by: two anonymous referees

\section{References}

Basu, D., Das, K., Green, S., Janetzke, R., and Stamatakos, J.: Numerical simulation of surface waves generated by a subaerial landslide at Lituya Bay Alaska, J. Offshore Mech. Arct., 132, 10-21, 2010.

Biscarini, C.: Computational fluid dynamics modelling of landslide generated water waves, Landslides, 7, 117-124, 2010.

Bosa, S. and Petti, M.: Shallow water numerical model of the wave generated by the Vajont landslide, Environ Modell Softw., 26 (4), 406-418, 2011.

Ceryan, S., Zorlu, K., Gokceoglu, C., and Temel, A.: The use of cation packing index for characterizing the weathering degree of granitic rocks, Eng. Geol., 98, 60-74, 2008.

Chow, V. T.: Open channel hydraulics, McGraw-Hill, New York, NY, 1960.

Duman, T.: The largest landslide dam in Turkey: Tortum landslide, Eng. Geol., 104 (1-2), 66-79, 2009.

Fritz, H. M., Hager, W. H., and Minor, H. E.: Lituya bay case: rockslide impact and wave run-up., Sci Tsunami Possible damageds, 19(1), 3-22, 2001

Fritz, H. M., Hager, W. H., and Minor, H. E.: Near field characteristics of landslide generated impulse waves, J. Waterw. Port C.-ASCE, 130, 287-300, 2004.

Genc, S.: Structural and geomorphological aspects of the Çatak landslide, NE Turkey, Q. J. Eng. Geol. Hydroge., 26 (2), 99-108, 1993.

Genevois, R. and Ghirotti, M.: The 1963 Vaiont Landslide, Giornale di Geologia Applicata, 1, 41-52, 2005.

Gokceoglu, C., Sonmez, H., Nefeslioglu, H. A., Duman, T., and Can, T.: The 17 March 2005 Kuzulu landslide (Sivas, Turkey) and landslide-possible damaged map of its near vicinity, Eng. Geol., 81 (1), 65-83, 2005.

Gokceoglu, C., Tunusluoglu, M. C., Gorum, T., Tur, H., Gokasan, E., Tekkeli, A. B., Batuk, F., and Alp, H.: Description of dynamics of the Tuzla Landslide and its implications for further landslides in the northern slope and shelf of the Cinarcik Basin (Marmara Sea, Turkey), Eng. Geol., 106 (3-4), 133-153, 2009.

Guven, I. H.: 1/250000 scaled geological and metallogenical map of the Eastern Black Sea Reghion, MTA Report (in Turkish, unpublished), 1993. 
Hall, J. V. and Watts, G. M.: Laboratory investigation of the vertical rise of solitary waves on impermeable slopes, Tec. Memo.33, U.S. Army Corps. of Engineers, Beach Erosion Board, 1953.

Heinrich, P.: Nonlinear water waves generated by submarine and aerial landslides, J. Waterw. Port C.-ASCE, 118(3), 249-266, 1992.

Huber, A., and Hager, W. H.: Forecasting impulse waves in reservoirs, in Dix-neuvième Congrès des Grands Barrages, Florence, Commission Internationale des Grands Barrages, 9931005, 1997.

Kamphuis, J. W. and Bowering, R. J.: Impulse waves generated by landslides, in: Proceeding of $12^{\text {th }}$ Coastal Engineering Con., ASCE, 1575-1588, 1970.

Kofoed-Hansen, H., Gimenez, G. E., and Kronborg, P.: Modeling of landslide-generated waves in MIKE21: Proceedings 4th DHI Software Conference, Helsingør, Denmark, 1-21, 2001.

Kranzer, H. C. and Keller, J. B.: Water waves produced by explosions, J. Appl. Phys., 398-407, 1960.

Kutlu, G. K.: Geotechnical report about Hardisagir landslide located on left abutment of the Kurtun Dam reservoir area, D.S., $22^{\text {th }}$ Region Directory, Trabzon, Open File Rep., 30 pp., 2009.

Le Mehaute, B. and Wang, S.: Water waves generated by underwater explosion, World Scientific, 525 pp., 1996.

Monaghan, J. J., and Kos, A.: Solitary waves on a Cretan beach, J. Waterw. Port C.-ASCE, 125(3), 145-154, 2000.

Mueller, D.: Auflaufen und Überschwappen von Impulswellen an Talsperren, VAW-Mitteilung 137, edited by: Vischer, D., Versuchsanstalt für Wasserbau, Hydrologie und Glaziologie, ETH Zürich, 1995.

Noda, E.: Water waves generated by landslides, ASCE J. Waterways, Harbours and Coastal Engineering Division, 96(4), 835$855,1970$.

Ocakoglu, F., Gokceoglu, C., and Ercanoglu, M.: Dynamics of a complex mass movement triggered by heavy rainfall: a case study from NW Turkey, Geomorphology, 42 (3-4), 329-341, 2002.

Ozkuzukiran, S., Özkan, M. Y., Ozyazicioglu, M., and Yidiz, G. S.: Settlement behaviour of a concrete faced rock-fill dam, Geotechnical and Geol. Eng. J., 24, 6, 1665-1678, 2006.

Panizzo, A., De Girolamo, P., Di Risio, M., Maistri, A., and Petaccia, A.: Great landslide events in Italian artificial reservoirs, Nat. Hazards Earth Syst. Sci., 5, 733-740, doi:10.5194/nhess-5-7332005, 2005.

Pastor, M., Herreros, I., Fernandez Merodo, J. A., Mira, P., Haddad, B., Quecedo, M., Gonzalez, E., Alvarez-Cedron, C., and Drempetic, V.: Modelling of fast catastrophic landslides and impulse waves induced by them in fjords, lakes and reservoirs, Eng. Geol., 109, 124-134, 2009.

Prins, J. E.: Characteristics of waves generated by a local disturbance, Transactions, Am. Geophys. Union, 865-874, 1958.
Romstad, B., Harbitz, C. B., and Domaas, U.: A GIS method for assessment of rock slide tsunami hazard in all Norwegian lakes and reservoirs, Nat. Hazards Earth Syst. Sci., 9, 353-364, doi:10.5194/nhess-9-353-2009, 2009.

Slingerland, R. L. and Voight, B.: Occurrences, in: Properties and Predictive Models of Landslide-generated Water Waves, Chap. 9, edited by: Voight, B., Rockslides and Avalanches, 2, 317-397, 1979.

Slingerland, R. L. and Voight, B.: Evaluating possible damaged of landslide-induced water waves, J. Waterway Div.-ASCE, 108 (4), 504-512, 1982.

State Hydraulic Works: http://www.dsi.gov.tr/ last access: 15 June 2010.

Stoker, J. J.: Water waves, Interscience: New York, 567 pp., 1957.

Synolakis, C. E.: The run-up of solitary waves, J. Fluid Mech., 185, 523-545, 1987.

Varnes, D. J.: Slope movement types and processes, in: LandslidesAnalysis and Control: Transportation Research Board Special Report 176, edited by: Schuster, R. L. and Krizek, R. J., National Academy of Sciences, Washington, D.C., 11-33, 1978.

Walder, J. S., Watts, P., Sorensen, O. E., and Janssen, K.: Water waves generated by subaerial mass flows, J. Geophys. Res., 108(5), 2236-2255, 2003.

Watts, P., Grilli, S. T., Kirby, J. T., Fryer, G. J., and Tappin, D. R.: Landslide tsunami case studies using a Boussinesq model and a fully nonlinear tsunami generation model, Nat. Hazards Earth Syst. Sci., 3, 391-402, doi:10.5194/nhess-3-391-2003, 2003.

Watts, P.: Water waves generated by underwater landslides, Ph. D. thesis, California Inst. of Tech., Pasadena, CA, 319 pp., 1997.

Wieczorek, G. F., Geist, E. L., Motyka, R. J., and Jacob, M.: Possible damaged assessment of the tidal inlet landslide and potential subsequent tsunami, Glacier Bay National Park, Alaska, Landslides, 4, 205-215, 2007.

Wieczorek, G. F., Jakob, M., Motyka, R. J., Zirnheld, L. S., and Craw, P.: Preliminary assessment of landslide-induced wave possible damageds: Tidal Inlet, Glacier Bay National Park, Alaska, U.S. Geological Survey, Open File Report, 03-100, 2003.

Wiegel, R. L.: Laboratory studies of gravity waves generated by the movement of a submarine body, Trans. Am. Geophys. Union, 36, 759-774, 1955.

Wiegel, R. L.: Oceanographical Engineering, Prentice-Hall, Englewood Cliffs, New Jersey, 544 pp., 1964.

Wiegel, R. L., Noda, E. K., Kuba, E. M., Gee, D. M., and Tornberg, G.: Water waves generated by landslides in reservoirs, J. Waterw. Port. C. Div., ww2, 307-333, 1970.

WP/WLI (International Geotechnical Societies = UNESCO Working Party on World Landslide Inventory), A suggested method for describing the activity of a landslide, Bullet. Internat. Assoc. Eng. Geol., 47, 53-57, 1993. 